\title{
Genetic Screening of Plasticity Regulating Nogo-Type Signaling Genes in Migraine
}

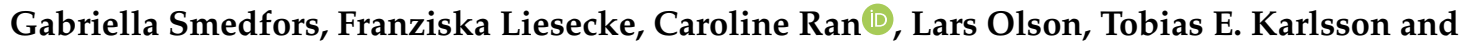 \\ Andrea Carmine Belin *D \\ Karolinska Institutet, Department of Neuroscience, Biomedicum, Solnavägen 9, 17177 Stockholm, Sweden; \\ gabriella.smedfors@ki.se (G.S.); franziska.liesecke@ki.se (F.L.); caroline.ran@ki.se (C.R.); lars.olson@ki.se (L.O.); \\ tobias.karlsson@ki.se (T.E.K.) \\ * Correspondence: andrea.carmine.belin@ki.se
}

Received: 18 October 2019; Accepted: 17 December 2019; Published: 20 December 2019

\begin{abstract}
Migraine is the sixth most prevalent disease in the world and a substantial number of experiments have been conducted to analyze potential differences between the migraine brain and the healthy brain. Results from these investigations point to the possibility that development and aggravation of migraine may include grey matter plasticity. Nogo-type signaling is a potent plasticity regulating system in the CNS and consists of ligands, receptors, co-receptors and modulators with a dynamic age- and activity-related expression in cortical and subcortical regions. Here we investigated a potential link between migraine and five key Nogo-type signaling genes: RTN4, OMGP, MAG, RTN4R and LINGO1, by screening 15 single nucleotide polymorphisms (SNPs) within these genes. In a large Swedish migraine cohort (749 migraine patients and 4032 controls), using a logistic regression with sex as covariate, we found that there was no such association. In addition, a haplotype analysis was performed which revealed three haplotype blocks. These blocks had no significant association with migraine. However, to robustly conclude that Nogo-type genotypes signaling do not influence the prevalence of migraine, further studies are encouraged.
\end{abstract}

Keywords: headache; signaling; SNP; association study; grey matter

\section{Introduction}

Migraine is the sixth most prevalent disease in the world [1]. While primarily associated with a burdening, often pulsating headache, migraine is frequently accompanied by other symptoms of altered sensory function. These symptoms vary in type, frequency and intensity between individuals. Common ones are nausea, vomiting, cutaneous allodynia, photophobia, phonophobia and osmophobia $[2,3]$. About one third of all migraine patients also experience the phenomenon of aura. Migraine with aura indicates transient neurological symptoms prior to the headache, often visual and/or a sensation of numbing and weakness in various parts of the body $[4,5]$. The migraine aura appears to be the result of cortical spreading depression which, in turn, has been associated with increased inflammation and subsequent activation of trigeminal afferents known to cause pain [6]. Migraine can be episodic (EM) with $<15$ attack days per month or chronic (CM) with $\geq 15$ attack days per month [7] and patients may change from EM to CM and vice versa [8]. The lifetime prevalence of migraine is around $13 \%$ in Sweden [9]. Chronic migraine is reported throughout populations with a prevalence of $2 \%$ [10]. The disease affects women two to three times more often than men, and episodes in women tend to correlate to hormonal levels peaking around menstruation [11,12]. In addition to a reduced quality of life [13], individuals with migraine have an increased risk of depression [14,15], with CM patients [16] and patients with aura [17] running a higher risk than EM patients. This comorbidity is hypothesized to be caused by a shared genetic profile $[18,19]$. Despite intense worldwide efforts in recent decades, 
the underlying mechanisms causing migraine are still not fully understood, even though genome-wide association studies (GWAS) have substantially increased our knowledge of the genetic background of this complex, polygenic and multifactorial disease. The most recent GWAS, including 375,000 individuals, associated migraine to a variety of genetic loci, pointing primarily to a vascular cause but also suggesting a role for disturbances of metal ion homeostasis [20].

A substantial number of experiments have been conducted to analyze potential differences between the migraine brain and the healthy brain. Brain activity and morphology have been scrutinized with different techniques, such as electrophysiology, electroencephalography, magnetoencephalography, magnetic resonance imaging (MRI) and positron emission tomography [21-27]. Results from these investigations have identified differences between control and migraine brains with regard to resting state activity and structure of gray and white matter. Differences have been detected in the frontal lobes, corpus callosum, the limbic system, cerebellum, the brainstem and nociceptive regions, although findings are not consistent across studies [22,24,25,27-36]. In addition to regional differences, cortical thickness has been reported to differ between migraine patients and controls, and even correlate to attack frequency [37]. However, as only few longitudinal studies have been published, it remains to conclusively establish whether alteration of cortical thickness is a response to repeated migraine attacks or a predisposing condition. Furthermore, it is not known whether these structural changes may normalize with adequate treatment or spontaneous remission. The results from published investigations nevertheless indicate that disease duration and attack frequency appear to correlate with degrees of altered structures, sensitization of excitability and with altered biochemical properties. Indeed, migraine has even been proposed to possibly be a progressive brain disease [26,32,35].

The central nervous system relies on a balanced level of plasticity to adequately wire and rewire neuronal connections. Nogo type signaling [38] is known as a potent negative regulator of structural synaptic plasticity in the CNS [39-42]. It consists of ligands, receptors, co-receptors and modulators with a dynamic age- and activity-related expression in cortical and subcortical regions $[43,44]$. Nogo-type signaling is executed primarily via Nogo receptor 1 (NgR1) through which the ligands Nogo-A, oligodendrocyte-myelin glycoprotein (OMGP) and myelin associated glycoprotein (MAG) can signal [45-49]. As NgR1 is a glycophosphatidylinositol (GPI) linked receptor; the signal transmission occurs with the assistance of co-receptors TROY or P75 and LINGO1 or AMIGO3 [50-53]. Activation of NgR1 initiates an intracellular cascade through the RhoA/ROCK pathway, leading to the depolymerization of cytoskeletal actin and the collapse of axon growth cones (Figure 1) $[41,48,54]$.

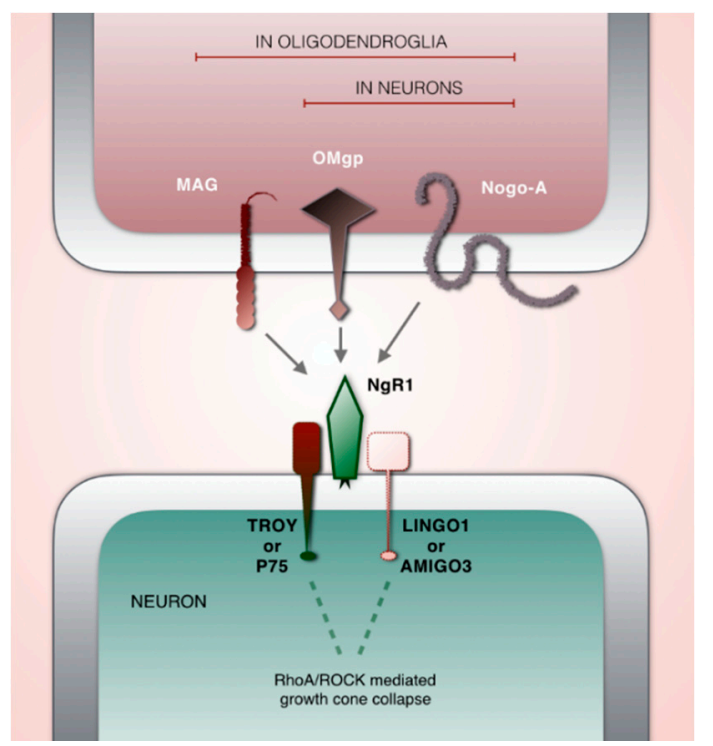

Figure 1. Schematic illustration of key players in Nogo-type signaling. Ligands: MAG, OMgp, Nogo-A. Key receptor: NgR1. Co-receptors: TROY or P75 and LINGO1 or AMIGO3. 
In epilepsy, initial seizure episodes tend to lower the threshold for additional attacks through kindling, a mechanism by which strongly activated brain pathways are thought to undergo structural synaptic plasticity. In support of this, animal modeling of electroconvulsive conditions have been shown to cause transient down regulation of $\mathrm{NgR} 1$ [55]. It has been suggested that migraine and affective illness may share the development of kindling with epilepsy [56]. Here, we ask if brain plasticity regulating genes involved in Nogo-type signaling are altered in migraine.

\section{Material and Methods}

Genetic information obtained from the Swedish Twin Registry was analyzed for this report, and the material has been described elsewhere [57]. All studies were performed in accordance with the Declaration of Helsinki, and procedures were carried out with written consent and adequate understanding of the test subjects. To conduct the following experiments, approval from the human subject's ethical review board of Stockholm (reference number 2007/644-31) was received.

The material consisted of 9897 Swedish individuals, of which 910 were classified to suffer from migraine, according to the International Classification of Headache Disorders 2nd edition ICHD-II [58]. This edition was extant at the time of the data collection and not reconciled with any changes in the newest edition (ICHD-3) affecting our study [7]. Classification was based on self-assessed questionnaires. We removed 1443 individuals from which information about migraine was not available. One twin per twin-couple was used for the association analyses. If one twin was diagnosed with migraine, this twin was kept for analysis, if both twins had migraine, one twin was randomly selected. In total, this caused removal of 4781 subjects. The cohort was checked for cryptic relatedness which removed 63 subjects, and for incorrectly assigned sex, which removed 36 subjects.

Genotyping was done on the Illumina HumanOmniExpress 12 v1.1 chip at the SNP\&SEQ Technology Platform, Uppsala University. Quality control (QC) of the material included missing genotype rate per person $<0.1$, missing genotype rate per single nucleotide polymorphism (SNP) $<0.1$, minor allele frequency (MAF) $<0.01$ and Hardy-Weinberg equilibrium $\left(1 \times 10^{-6}\right.$ for controls and 1 $\times 10^{-10}$ for cases) [59]. QC did not lead to the removal of any subjects. We found a 3.6-fold higher migraine frequency in women compared to men in our material (Table 1). This uneven, but expected, gender distribution in disease prevalence led us to use logistic regression with sex as a covariate for analysis. This controls for the risk of under- or overestimation of differences due to gender. We also performed a haplotype association test. Pairwise comparisons of markers were ignored for markers located $>500 \mathrm{kbp}$ apart.

Table 1. Distribution of individuals for analysis.

\begin{tabular}{ccccc}
\hline & Controls & Cases & Total & Migraine Frequency \\
\hline Men (\%) & $2138(53.0)$ & $162(21.6)$ & 2300 & $7.0 \%$ \\
Women (\%) & $1894(47.0)$ & $587(78.4)$ & 2481 & $23.7 \%$ \\
Total & 4032 & 749 & 4781 & $15.7 \%$ \\
\hline
\end{tabular}

The three Nogo receptor ligand genes RTN4 (Nogo-A), OMGP, and $M A G$, the key Nogo receptor gene RTN4R (NgR1), and the co-receptor LINGO1 were chosen for genetic analysis. To identify SNPs associated with these genes, we used the National Institute of Environmental Health Sciences software "LD TAG SNP Selection" selecting for SNPs in the central European population (CEU) [60] to match our Swedish migraine cohort. If the identified SNPs were not represented on the Illumina HumanOmni Express 12 v1.1 chip, we chose matching SNPs in high linkage disequilibrium (LD) ( $\left.\mathrm{r}^{2}: 0.96-1\right)$, in order to test for indirect association. This was done for 12 SNPs via the Ensembl software (Table 2). For nine of the TAG SNPs, replacement SNPs were not available, therefore, they were excluded from the study (Table S1). The remaining TAG SNPs and replacement SNPs were tested for high LD to exclude SNP-pairs with $\mathrm{r}^{2}>0.2$ [61]. This step led to the rejection of 17 additional SNPs, leaving 15 SNPs for further analysis. 
Table 2. Nogo-type signaling single nucleotide polymorphism (SNP) selection for association analysis.

\begin{tabular}{|c|c|c|c|c|}
\hline Chr & Gene Symbol & TAG SNPs of Interest & Replacement SNP & After Exclusion of SNPs in LD with $r^{2}>0.2$ \\
\hline 2 & RTN4 & rs6545465 & rs17046589 & rs17046589 \\
\hline 2 & RTN4 & rs7562292 & rs6545466 & - \\
\hline 2 & RTN4 & rs10084445 & rs6715980 & rs6715980 \\
\hline 2 & RTN4 & rs7584386 & rs7584354 & - \\
\hline 2 & RTN4 & rs2580765 & - & rs2580765 \\
\hline 2 & RTN4 & rs17046594 & rs17046570 & - \\
\hline 2 & RTN4 & rs3198123 & - & - \\
\hline 2 & RTN4 & rs2580769 & - & - \\
\hline 2 & RTN4 & rs2588517 & - & - \\
\hline 2 & RTN4 & rs2588519 & - & - \\
\hline 2 & RTN4 & rs2864052 & - & - \\
\hline 2 & RTN4 & rs10496037 & - & rs10496037 \\
\hline 2 & RTN4 & rs2920898 & - & - \\
\hline 15 & LINGO1 & rs907395 & rs907396 & rs907396 \\
\hline 15 & LINGO1 & rs8024724 & rs8023571 & rs8023571 \\
\hline 15 & LINGO1 & rs3743481 & - & - \\
\hline 15 & LINGO1 & rs7162113 & - & - \\
\hline 15 & LINGO1 & rs3144 & - & rs3144 \\
\hline 15 & LINGO1 & rs1877298 & rs8028788 & rs8028788 \\
\hline 17 & OMG & rs11080149 & - & rs11080149 \\
\hline 19 & MAG & rs12461927 & rs720308 & - \\
\hline 19 & MAG & rs12185485 & rs3746248 & - \\
\hline 19 & MAG & rs10414549 & - & - \\
\hline 19 & MAG & rs9304870 & - & rs9304870 \\
\hline 19 & MAG & rs6510476 & - & rs6510476 \\
\hline 19 & MAG & rs2301600 & - & rs2301600 \\
\hline 19 & MAG & rs10411883 & rs11669734 & - \\
\hline 22 & RTN4R & rs854971 & rs701427 & rs701427 \\
\hline 22 & RTN4R & rs1567871 & - & rs1567871 \\
\hline 22 & RTN4R & rs855050 & - & rs855050 \\
\hline 22 & RTN4R & rs1807466 & - & - \\
\hline 22 & RTN4R & rs887765 & - & - \\
\hline
\end{tabular}

Table of 32 SNPs associated with five Nogo-type signaling genes and their replacement SNPs if original SNPs were not available on the Illumina OmniExpress chip. SNPs in LD with $\mathrm{r} 2>0.2$ were excluded. SNPs in the rightmost column were used for further association analysis with migraine in the Swedish twin cohort. Chr $=$ Chromosome, $\mathrm{SNP}=$ Single Nucleotide Polymorphism, LD = Linkage Disequilibrium.

Genetic analyses were made with PLINK versions 1.07 and 1.9 [62,63]. Power calculations were made online with help of the Genetic Association Study Power Calculator [64] with MAF reference-values from National Center for Biotechnology Information [65], choosing the Northern Sweden population (Table 3). Haplotype analysis was made with the Haploview software from the Broad institute [66]. For graphical and further statistical analysis, we used $\mathrm{R}$ and RStudio version 1.1.456 [67,68]. 
Table 3. Fifteen SNPs associated with Nogo-type signaling investigated for association to migraine in a Swedish cohort.

\begin{tabular}{|c|c|c|c|c|c|c|c|c|c|}
\hline Gene & SNP & Function & $\begin{array}{l}\text { Minor } \\
\text { Allele }\end{array}$ & $\begin{array}{l}\text { MAF } \\
\text { NCBI }\end{array}$ & $\begin{array}{l}\text { MAF } \\
\text { Cases }\end{array}$ & $\begin{array}{c}\text { MAF } \\
\text { Controls }\end{array}$ & OR $(95 \% \mathrm{CI})$ & $P$-Value & $\begin{array}{c}\text { Corrected } \\
P \text {-Value }\end{array}$ \\
\hline RTN4 & rs2580765 & Intron & $\mathrm{C}$ & 0.46 & 0.46 & 0.43 & $1.09(0.97-1.22)$ & 0.14 & 1 \\
\hline RTN4 & rs6715980 & Intron & A & 0.06 & 0.07 & 0.07 & $1.04(0.83-1.29)$ & 0.76 & 1 \\
\hline RTN4 & rs17046589 & Intron & G & 0.22 & 0.18 & 0.18 & $1.003(0.87-1.16)$ & 0.96 & 1 \\
\hline RTN4 & rs10496037 & Intron & $\mathrm{T}$ & 0.11 & 0.12 & 0.11 & $1.08(0.91-1.29)$ & 0.36 & 1 \\
\hline LINGO1 & rs3144 & 3' UTR region & $\mathrm{C}$ & 0.40 & 0.37 & 0.37 & $0.97(0.86-1.09)$ & 0.56 & 1 \\
\hline LINGO1 & rs907396 & Intron & G & 0.40 & 0.40 & 0.38 & $1.1(0.98-1.24)$ & 0.11 & 1 \\
\hline LINGO1 & rs8023571 & Intron & $\mathrm{T}$ & 0.12 & 0.12 & 0.12 & $1.02(0.86-1.22)$ & 0.79 & 1 \\
\hline LINGO1 & rs8028788 & Intron & C & 0.04 & 0.05 & 0.04 & $1.17(0.91-1.52)$ & 0.23 & 1 \\
\hline OMGP & rs11080149 & Coding & $\mathrm{T}$ & 0.14 & 0.17 & 0.15 & $1.08(0.92-1.25)$ & 0.35 & 1 \\
\hline MAG & rs6510476 & Intron & G & 0.16 & 0.18 & 0.18 & $1.01(0.87-1.17)$ & 0.92 & 1 \\
\hline MAG & rs2301600 & Coding & $\mathrm{T}$ & 0.24 & 0.25 & 0.23 & $1.07(0.94-1.22)$ & 0.33 & 1 \\
\hline MAG & rs9304870 & Intron & G & 0.33 & 0.38 & 0.38 & $1.03(0.91-1.15)$ & 0.66 & 1 \\
\hline RTN4R & rs701427 & Intron & A & 0.31 & 0.32 & 0.34 & $0.93(0.83-1.05)$ & 0.26 & 1 \\
\hline RTN4R & rs1567871 & Intron & $\mathrm{T}$ & 0.26 & 0.25 & 0.25 & $1.0(0.88-1.14)$ & 1.00 & 1 \\
\hline RTN4R & rs855050 & Intron & G & 0.49 & 0.51 & 0.50 & $1.04(0.93-1.17)$ & 0.47 & 1 \\
\hline
\end{tabular}

$\mathrm{Chr}=$ Chromosome, SNP = Single Nucleotide Polymorphism, 3' UTR = three prime untranslated region, MAF $=$ Minor Allele Frequency, $\mathrm{OR}=$ Odds Ratio, $\mathrm{CI}=$ confidence interval, $P$-values $=\alpha 0.05$, Corrected $P$-value $=$ Bonferroni correction based on $\alpha / 15$ ( $\mathrm{nr}$ of SNPs).

\section{Results}

Nogo-type signaling involves a broad number of receptors, ligands, co-receptors and modulators. To increase the power of our study, we chose to analyze five key genes: RTN4, RTN4R, LINGO1, $O M G P$, and MAG. After QC (see methods), our cohort consisted of 4781 individuals, 749 cases and 4032 controls, and we selected 15 SNPs in, or in proximity to, these genes for the association analysis (Table 3). When we used the association analysis in the form of a logistic regression analysis with sex as a covariate due to the expected 3.6 times higher prevalence of migraine among females in our cohort, we did not reveal an association between any of these 15 SNPs and migraine.

As haplotypes are considered more valuable to predict genetic correlations with disease outcome than single SNPs alone [69], we also performed a haplotype analysis. The analysis revealed three haplotype blocks (Table 4). These blocks had no significant association with migraine.

Table 4. Identified haplotypes in three genes associated to Nogo-type signaling were not associated to migraine.

\begin{tabular}{cccccc}
\hline \multirow{2}{*}{ Block } & Haplotype & Frequency & $\begin{array}{c}\text { Case-Control } \\
\text { Frequencies }\end{array}$ & P-Value \\
\hline \multirow{2}{*}{ LINGO1 } & \multirow{2}{*}{ rs907396 rs8023571 } & CC & 0.41 & $0.43 / 0.41$ & 0.17 \\
& & AC & 0.34 & $0.32 / 0.34$ & 0.21 \\
& & CT & 0.25 & $0.25 / 0.25$ & 0.83 \\
\hline \multirow{2}{*}{ MAG } & rs6510476 rs2301600 & AC & 0.59 & $0.58 / 0.59$ & 0.23 \\
& & AT & 0.23 & $0.25 / 0.23$ & 0.18 \\
& & GC & 0.18 & $0.18 / 0.18$ & 0.96 \\
\hline \multirow{2}{*}{ RTN4R } & rs701427 rs1567871 & TC & 0.50 & $0.49 / 0.50$ & 0.26 \\
& & GC & 0.38 & $0.39 / 0.38$ & 0.26 \\
& & TT & 0.12 & $0.12 / 0.12$ & 0.89 \\
\hline
\end{tabular}

To estimate what effect-size we would need to be able to reach a power of $80 \%$ or $95 \%$, we performed power calculations based on the MAF of each SNP in our population (Figure 2). The two levels of power were selected with the rationale that this was a study of collected data from a very 
specific population. Hence, a replication study where each replicate would decrease the risk of missing an actual effect is hard to obtain. This is based on the commonly chosen power of $80 \%$ which would declare $1 / 5$ of the SNPs having a significant association as non-significant.

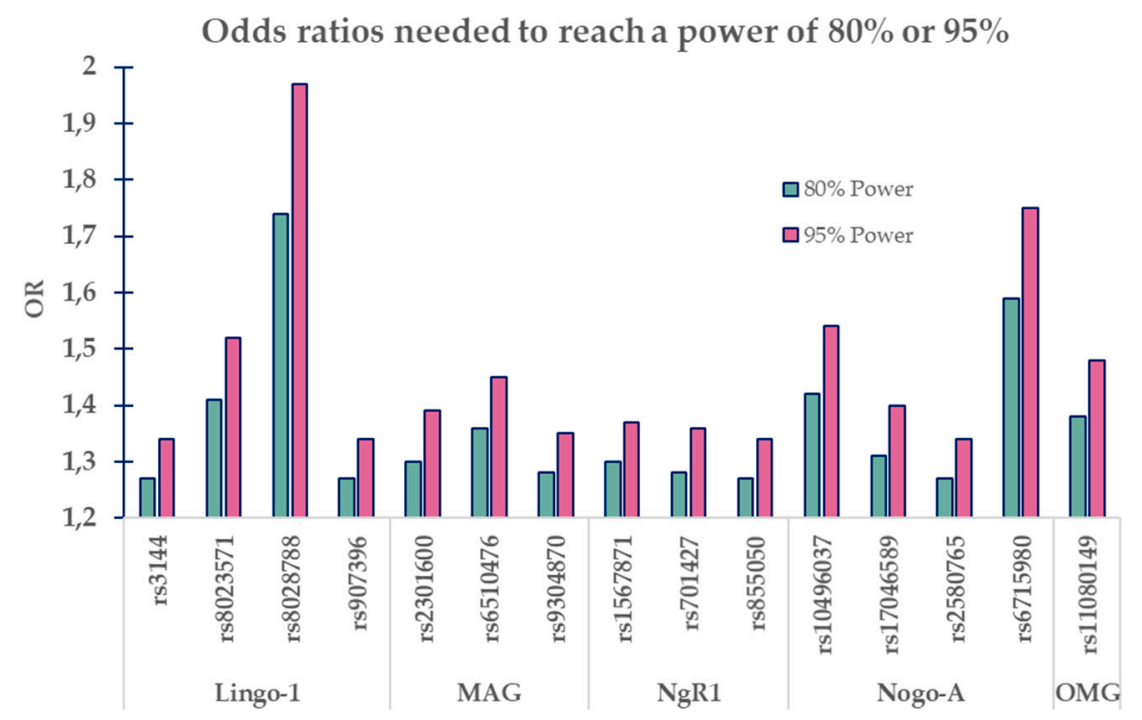

Figure 2. Graph illustrating needed odds ratios (ORs) for SNP's minor allele frequencies to reach a power of $80 \%$ or $95 \%$.

\section{Discussion}

Migraine carries dire consequences for the suffering patients, including socio-economic misfortune. In the United States alone, the societal direct and indirect costs were estimated to be $\$ 36$ billion in 2016 [70]. Progress in the understanding of migraine pathophysiology is central to discover better therapies.

It has repeatedly been demonstrated how the migraine brain differs morphologically from the healthy brain in several brain regions. Moreover, these alterations appear to progress over time and with attack frequency [25,28,31-35]. However, there may well be alterations at the level of structural synaptic plasticity that cannot be detected in vivo in humans with available methods. Here, we investigated a potential association between a key plasticity-regulating system in the CNS-Nogo-type signaling-and migraine.

Microstructural alterations associated with Nogo-type signaling cannot be investigated with MRI and related methods, since voxel sizes trespass the size of dendrites and dendritic spines [32,71]. Since satisfying animal models of migraine are lacking, we chose a genetic approach to investigate Nogo-type signaling in migraine. We looked at the frequency of 15 SNPs from five genes primarily associated with Nogo-type signaling; the ligands RTN4, OMGP and MAG, the key receptor RTN4R, and the co-receptor LINGO1. The most recent GWAS of migraine identified 38 suspected loci [20], none of them a part of Nogo-type signaling. However, as GWAS handles huge numbers of genetic targets, it not only suffers risk of detecting false-positive associations, its need for profound correction for multiple testing may result in loss of smaller effects.

We analyzed SNPs related to Nogo-type signaling in a cohort of the Swedish Twin Registry, consisting of 749 migraine cases and 4032 controls where the migraine frequency was 3.6 times higher among women. When analyzing the association of the Nogo SNPs with sex as covariate, we found no significant association of any of the selected genes to migraine. Our findings decrease the likelihood of altered Nogo signaling being a risk factor for migraine but does not exclude this possibility.

Migraine patients differ regarding age of onset, occurrence of aura, frequency of attacks, attack-causing stimuli, and attack intensity. Furthermore, different patients respond to different medications. For some patients, over the counter painkillers can abort an attack while for other patients, 
extensive polypharmacological treatments may not be sufficient. These differences in response to medication presumably reflect different genetic profiles [72]. A limiting aspect of the current study is that information about these variations among the migraine patients was lacking.

ICHD defines chronic migraine as having fifteen or more attack days per month. However, already in patients with episodic migraine, suffering from three attack days (and more, but less than 15) per month have been shown to be associated with structural differences [32]. The fact that structural changes are noticeable at a five times lower frequency than the criteria of the chronic state increases the incentive for a more aggressive therapy to alleviate symptoms by reducing attack frequency early on, also in episodic migraine patients.

Our results should also be viewed in light of the power analysis which revealed that with our sample size, we would need odds ratios extending the ORs acquired in this report, and the ORs in the last migraine GWAS [20]. Our ORs were $0.97-1.17$ and the SNPs positively associated with migraine in the migraine GWAS had ORs ranges of $0.88-1.11$. Our power calculation pointed out that for $80 \%$ power, our SNPs would need ORs between 1.27 and 1.74 and for $95 \%$ power, ORs of 1.34-1.97. Thus, this study defines a theoretical upper level of how strongly these SNPs could influence the prevalence of migraine. When more studies emerge, this initial estimated effect can be improved, and a more exact effect/non-effect can be established.

\section{Conclusions}

Nogo-type signaling comprises a potent negative regulator system for structural synaptic plasticity. We investigated a potential link between Nogo-type signaling and migraine based on the frequency of 15 SNPs associated with five genes involved in Nogo-type signaling in 4781 individuals, of which 749 had migraine, in a Swedish cohort. We did not detect an association of any of the 15 SNPs with migraine. Our findings suggest that altered Nogo-type signaling does not strongly affect the pathophysiology of migraine.

Supplementary Materials: The following are available online at http:/www.mdpi.com/2076-3425/10/1/5/s1, Table S1: Excluded SNPs due to absence on the genotyping chip and lack of replacement SNPs in high LD on the current chip.

Author Contributions: Conceptualization, A.C.B. and T.E.K.; methodology, A.C.B., T.E.K.; software, F.L.; validation, A.C.B., C.R. and F.L.; formal analysis, G.S.; investigation, G.S., F.L., C.R.; resources, A.C.B., L.O.; data curation, G.S.; writing — original draft preparation, G.S.; writing — review and editing, G.S., T.E.K., F.L., C.R., L.O., A.C.B.; visualization, G.S.; supervision, T.E.K., L.O., A.C.B.; project administration, A.C.B.; funding acquisition, L.O., A.C.B., G.S. All authors have read and agreed to the published version of the manuscript.

Funding: The Swedish Research Council 2017-01096 (ACB), the Swedish Brain Foundation FO2018-0008 (ACB, CR), Karolinska Institutet Research Funds 2018-01738 (ACB), Magnus Bergvalls Stiftelse 2018-02920 (CR), the Swedish Research Council K2012-62X-03185-42-4 (LO), the Swedish Brain Foundation 2018 (LO), a donation by Per Nydahl 2019 (LO), and the Karolinska Institute Clinical Scientist Training Programme (CSTP) 2013 (GS), Karolinska Institutet Program for “Forskar AT" 2016 (GS).

Conflicts of Interest: The authors declare no conflict of interest.

\section{References}

1. Vos, T.; Abajobir, A.A.; Abate, K.H.; Abbafati, C.; Abbas, K.M.; Abd-Allah, F.; Abdulkader, R.S.; Abdulle, A.M.; Abebo, T.A.; Abera, S.F.; et al. Global, regional, and national incidence, prevalence, and years lived with disability for 328 diseases and injuries for 195 countries, 1990-2016: A systematic analysis for the Global Burden of Disease Study 2016. Lancet 2017, 390, 1211-1259. [CrossRef]

2. Burstein, R.; Noseda, R.; Borsook, D. Migraine: Multiple processes, complex Pathophysiology. J. Neurosci. 2015, 35, 6619-6629. [CrossRef] [PubMed]

3. Schwedt, T.J.; Larson-Prior, L.; Coalson, R.S.; Nolan, T.; Mar, S.; Ances, B.M.; Benzinger, T.; Schlaggar, B.L. Allodynia and descending pain modulation in migraine: A resting state functional connectivity analysis. Pain Med. 2014, 15, 154-165. [CrossRef] [PubMed] 
4. Leone, M.; Proietti Cecchini, A. Advances in the understanding of cluster headache. Expert Rev. Neurother. 2017, 17, 165-172. [CrossRef] [PubMed]

5. Stewart, W.F.; Linet, M.S.; Celentano, D.D.; Natta, M.V.; Ziegler, D. Age- and sex-specific incidence rates of migraine with and without visual aura. Am. J. Epidemiol. 1991, 134, 1111-1120. [CrossRef] [PubMed]

6. Cui, Y.; Kataoka, Y.; Watanabe, Y. Role of cortical spreading depression in the pathophysiology of migraine. Neurosci. Bull. 2014, 30, 812-822. [CrossRef]

7. Headache Classification Committee of the International Headache Society (IHS) The International Classification of Headache Disorders, 3rd edition. Cephalalgia 2018, 38, 1-211. [CrossRef]

8. Manack, A.N.; Buse, D.C.; Lipton, R.B. Chronic migraine: Epidemiology and disease burden. Curr. Pain Headache Rep. 2011, 15, 70-78. [CrossRef]

9. Dahlöf, C.; Linde, M. One-year prevalence of migraine in Sweden: A population-based study in adults. Cephalalgia 2001, 21, 664-671. [CrossRef]

10. May, A.; Schulte, L.H. Chronic migraine: Risk factors, mechanisms and treatment. Nat. Rev. Neurol. 2016, 12, 455-464. [CrossRef]

11. Rutberg, S.; Öhrling, K. Migraine-More than a headache: Women's experiences of living with migraine. Disabil. Rehabil. 2012, 34, 329-336. [CrossRef]

12. Vetvik, K.G.; MacGregor, E.A. Sex differences in the epidemiology, clinical features, and pathophysiology of migraine. Lancet Neurol. 2017, 16, 76-87. [CrossRef]

13. Taşkapilioğlu, Ö.; Karli, N. Assessment of quality of life in migraine. Noropsikiyatri Ars. 2013, 50, S60-S64.

14. Ball, H.; Samaan, Z.; Brewster, S.; Craddock, N.; Gill, M.; Korszun, A.; Maier, W.; Middleton, L.; Mors, O.; Owen, M.; et al. Depression, migraine with aura and migraine without wura: Their familiality and interrelatedness. Cephalalgia 2009, 29, 848-854. [CrossRef] [PubMed]

15. Breslau, N.; Lipton, R.B.; Stewart, W.F.; Schultz, L.R.; Welch, K.M.A. Comorbidity of migraine and depression: Investigating potential etiology and prognosis. Neurology 2003, 60, 1308-1312. [CrossRef]

16. Hamelsky, S.W.; Lipton, R.B. Psychiatric comorbidity of migraine. Headache J. Head Face Pain 2006, 46, 1327-1333. [CrossRef]

17. De Boer, I.; van den Maagdenberg, A.M.J.M.; Terwindt, G.M. Advance in genetics of migraine. Curr. Opin. Neurol. 2019, 32, 413-421. [CrossRef]

18. Stam, A.H.; de Vries, B.; Janssens, A.C.J.W.; Vanmolkot, K.R.J.; Aulchenko, Y.S.; Henneman, P.; Oostra, B.A.; Frants, R.R.; van den Maagdenberg, A.M.J.M.; Ferrari, M.D.; et al. Shared genetic factors in migraine and depression. Neurology 2010, 74, 288-294. [CrossRef]

19. Yang, Y.; Zhao, H.; Boomsma, D.I.; Ligthart, L.; Belin, A.C.; Smith, G.D.; Esko, T.; Freilinger, T.M.; Hansen, T.F.; Ikram, M.A.; et al. Molecular genetic overlap between migraine and major depressive disorder. Eur. J. Hum. Genet. 2018, 26, 1202-1216. [CrossRef]

20. Gormley, P.; Anttila, V.; Winsvold, B.S.; Palta, P.; Esko, T.; Pers, T.H.; Farh, K.-H.; Cuenca-Leon, E.; Muona, M.; Furlotte, N.A.; et al. Meta-analysis of 375,000 individuals identifies 38 susceptibility loci for migraine. Nat. Genet. 2016, 48, 856-866. [CrossRef]

21. Colombo, B.; Rocca, M.A.; Messina, R.; Guerrieri, S.; Filippi, M. Resting-state fMRI functional connectivity: A new perspective to evaluate pain modulation in migraine? Neurol. Sci. 2015, 36, 41-45. [CrossRef] [PubMed]

22. Coppola, G.; Petolicchio, B.; Di Renzo, A.; Tinelli, E.; Di Lorenzo, C.; Parisi, V.; Serrao, M.; Calistri, V.; Tardioli, S.; Cartocci, G.; et al. Cerebral gray matter volume in patients with chronic migraine: Correlations with clinical features. J. Headache Pain 2017, 18, 115. [CrossRef] [PubMed]

23. Garcia-Larrea, L.; Bastuji, H. Pain and consciousness. Prog. Neuropsychopharmacol. Biol. Psychiatry 2017. [CrossRef] [PubMed]

24. Liu, H.; Ge, H.; Xiang, J.; Miao, A.; Tang, L.; Wu, T.; Chen, Q.; Yang, L.; Wang, X. Resting state brain activity in patients with migraine: A magnetoencephalography study. J. Headache Pain 2015, 16. [CrossRef]

25. Lovati, C.; Giani, L.; Mele, F.; Sinelli, A.; Tien, T.T.; Preziosa, G.; Mariani, C. Brain plasticity and migraine transformation: fMRI evidences. Expert Rev. Neurother. 2016, 16, 1413-1425. [CrossRef]

26. Messina, R.; Rocca, M.A.; Colombo, B.; Pagani, E.; Falini, A.; Goadsby, P.J.; Filippi, M. Gray matter volume modifications in migraine: A cross-sectional and longitudinal study. Neurology 2018, 91, e280-e292. [CrossRef]

27. Zhang, J.; Wu, Y.-L.; Su, J.; Yao, Q.; Wang, M.; Li, G.-F.; Zhao, R.; Shi, Y.-H.; Zhao, Y.; Zhang, Q.; et al. Assessment of gray and white matter structural alterations in migraineurs without aura. J. Headache Pain 2017, 18, 74. [CrossRef] 
28. Afridi, S.K.; Giffin, N.J.; Kaube, H.; Friston, K.J.; Ward, N.S.; Frackowiak, R.S.J.; Goadsby, P.J. A Positron emission tomographic study in spontaneous migraine. Arch. Neurol. 2005, 62, 1270-1275. [CrossRef]

29. Akerman, S.; Romero-Reyes, M.; Holland, P.R. Current and novel insights into the neurophysiology of migraine and its implications for therapeutics. Pharmacol. Ther. 2017, 172, 151-170. [CrossRef]

30. Maleki, N.; Becerra, L.; Brawn, J.; McEwen, B.; Burstein, R.; Borsook, D. Common hippocampal structural and functional changes in migraine. Brain Struct. Funct. 2013, 218, 903-912. [CrossRef]

31. Neeb, L.; Bastian, K.; Villringer, K.; Israel, H.; Reuter, U.; Fiebach, J.B. Structural gray matter alterations in chronic migraine: Implications for a progressive disease? Headache J. Head Face Pain 2017, 57, 400-416. [CrossRef] [PubMed]

32. Schmitz, N.; Admiraal-Behloul, F.; Arkink, E.B.; Kruit, M.C.; Schoonman, G.G.; Ferrari, M.D.; Buchem, M.A.V. Attack frequency and disease duration as indicators for brain damage in migraine. Headache J. Head Face Pain 2008, 48, 1044-1055. [CrossRef] [PubMed]

33. Soheili-Nezhad, S.; Sedghi, A.; Schweser, F.; Eslami Shahr Babaki, A.; Jahanshad, N.; Thompson, P.M.; Beckmann, C.F.; Sprooten, E.; Toghae, M. Structural and functional reorganization of the brain in migraine without aura. Front. Neurol. 2019, 10. [CrossRef] [PubMed]

34. Tolner, E.A.; Chen, S.-P.; Eikermann-Haerter, K. Current understanding of cortical structure and function in migraine. Cephalalgia 2019, 39, 1683-1699. [CrossRef] [PubMed]

35. Yu, D.; Yuan, K.; Qin, W.; Zhao, L.; Dong, M.; Liu, P.; Yang, X.; Liu, J.; Sun, J.; Zhou, G.; et al. Axonal loss of white matter in migraine without aura: A tract-based spatial statistics study. Cephalalgia 2013, 33, 34-42. [CrossRef]

36. Yuan, K.; Qin, W.; Liu, P.; Zhao, L.; Yu, D.; Zhao, L.; Dong, M.; Liu, J.; Yang, X.; von Deneen, K.M.; et al. Reduced fractional anisotropy of corpus callosum modulates inter-hemispheric resting state functional connectivity in migraine patients without aura. PLoS ONE 2012, 7, e45476. [CrossRef]

37. Lai, T.-H.; Protsenko, E.; Cheng, Y.-C.; Loggia, M.L.; Coppola, G.; Chen, W.-T. Neural plasticity in common forms of chronic headaches. Neural Plast. 2015, 2015. [CrossRef]

38. Schwab, M.E. Functions of Nogo proteins and their receptors in the nervous system. Nat. Rev. Neurosci. 2010, 11, 799-811. [CrossRef]

39. Karlén, A.; Karlsson, T.E.; Mattsson, A.; Lundströmer, K.; Codeluppi, S.; Pham, T.M.; Bäckman, C.M.; Ogren, S.O.; Aberg, E.; Hoffman, A.F.; et al. Nogo receptor 1 regulates formation of lasting memories. Proc. Natl. Acad. Sci. USA 2009, 106, 20476-20481. [CrossRef]

40. Karlsson, T.E.; Smedfors, G.; Brodin, A.T.S.; Åberg, E.; Mattsson, A.; Högbeck, I.; Wellfelt, K.; Josephson, A.; Brené, S.; Olson, L. NgR1: A tunable sensor regulating memory formation, synaptic, and dendritic plasticity. Cereb. Cortex 2016, 26, 1804-1817. [CrossRef]

41. Kellner, Y.; Fricke, S.; Kramer, S.; Iobbi, C.; Wierenga, C.J.; Schwab, M.E.; Korte, M.; Zagrebelsky, M. Nogo-A controls structural plasticity at dendritic spines by rapidly modulating actin dynamics. Hippocampus 2016, 26, 816-831. [CrossRef] [PubMed]

42. Zagrebelsky, M.; Lonnemann, N.; Fricke, S.; Kellner, Y.; Preuß, E.; Michaelsen-Preusse, K.; Korte, M. Nogo-A regulates spatial learning as well as memory formation and modulates structural plasticity in the adult mouse hippocampus. Neurobiol. Learn. Mem. 2017, 138, 154-163. [CrossRef] [PubMed]

43. Josephson, A.; Widenfalk, J.; Widmer, H.W.; Olson, L.; Spenger, C. NOGO mRNA expression in adult and fetal human and rat nervous tissue and in weight drop injury. Exp. Neurol. 2001, 169, 319-328. [CrossRef] [PubMed]

44. Smedfors, G.; Olson, L.; Karlsson, T.E. A Nogo-Like Signaling Perspective from Birth to Adulthood and in Old Age: Brain Expression Patterns of Ligands, Receptors and Modulators. Front. Mol. Neurosci. 2018, 11. [CrossRef]

45. Cafferty, W.B.J.; Duffy, P.; Huebner, E.; Strittmatter, S.M. MAG and OMgp synergize with Nogo-A to restrict axonal growth and neurological recovery after spinal cord trauma. J. Neurosci. 2010, 30, 6825-6837. [CrossRef]

46. Domeniconi, M.; Cao, Z.; Spencer, T.; Sivasankaran, R.; Wang, K.; Nikulina, E.; Kimura, N.; Cai, H.; Deng, K.; Gao, Y.; et al. Myelin-associated glycoprotein interacts with the Nogo66 receptor to inhibit neurite outgrowth. Neuron 2002, 35, 283-290. [CrossRef]

47. Fournier, A.E.; GrandPre, T.; Strittmatter, S.M. Identification of a receptor mediating Nogo-66 inhibition of axonal regeneration. Nature 2001, 409, 341-346. [CrossRef] 
48. Niederöst, B.; Oertle, T.; Fritsche, J.; McKinney, R.A.; Bandtlow, C.E. Nogo-A and myelin-associated glycoprotein mediate neurite growth inhibition by antagonistic regulation of RhoA and Rac1. J. Neurosci. 2002, 22, 10368-10376. [CrossRef]

49. Wang, K.C.; Koprivica, V.; Kim, J.A.; Sivasankaran, R.; Guo, Y.; Neve, R.L.; He, Z. Oligodendrocyte-myelin glycoprotein is a Nogo receptor ligand that inhibits neurite outgrowth. Nature 2002, 417, 941-944. [CrossRef]

50. Ahmed, Z.; Douglas, M.R.; John, G.; Berry, M.; Logan, A. AMIGO3 is an NgR1/p75 co-receptor signalling axon growth inhibition in the acute phase of adult central nervous system injury. PLoS ONE 2013, 8, e61878. [CrossRef]

51. Iobbi, C.; Korte, M.; Zagrebelsky, M. Nogo-66 restricts synaptic strengthening via Lingo1 and the ROCK2-Cofilin pathway to control actin dynamics. Cereb. Cortex 2017, 27, 2779-2792. [CrossRef] [PubMed]

52. Park, J.B.; Yiu, G.; Kaneko, S.; Wang, J.; Chang, J.; He, X.L.; Garcia, K.C.; He, Z. A TNF receptor family member, TROY, is a coreceptor with Nogo receptor in mediating the inhibitory activity of myelin inhibitors. Neuron 2005, 45, 345-351. [CrossRef] [PubMed]

53. Wang, K.C.; Kim, J.A.; Sivasankaran, R.; Segal, R.; He, Z. P75 interacts with the Nogo receptor as a co-receptor for Nogo, MAG and OMgp. Nature 2002, 420, 74-78. [CrossRef] [PubMed]

54. Karlsson, T.E.; Wellfelt, K.; Olson, L. Spatiotemporal and long lasting modulation of 11 key Nogo signaling genes in response to strong neuroexcitation. Front. Mol. Neurosci. 2017, 10, 94. [CrossRef] [PubMed]

55. Nordgren, M.; Karlsson, T.; Svensson, M.; Koczy, J.; Josephson, A.; Olson, L.; Tingström, A.; Brené, S. Orchestrated regulation of Nogo receptors, LOTUS, AMPA receptors and BDNF in an ECT model suggests opening and closure of a window of synaptic plasticity. PLOS ONE 2013, 8, e78778. [CrossRef] [PubMed]

56. Post, R.M.; Silberstein, S.D. Shared mechanisms in affective illness, epilepsy, and migraine. Neurology 1994, 44, 37-47.

57. Ran, C.; Graae, L.; Magnusson, P.K.; Pedersen, N.L.; Olson, L.; Belin, A.C. A replication study of GWAS findings in migraine identifies association in a Swedish case-control sample. BMC Med. Genet. 2014, 15, 38. [CrossRef]

58. The International Classification of Headache Disorders: 2nd edition. Cephalalgia 2004, 24 (Suppl. 1), 9-160.

59. Marees, A.T.; de Kluiver, H.; Stringer, S.; Vorspan, F.; Curis, E.; Marie-Claire, C.; Derks, E.M. A tutorial on conducting genome-wide association studies: Quality control and statistical analysis. Int. J. Methods Psychiatr. Res. 2018, 27. [CrossRef]

60. Xu, Z.; Taylor, J.A. SNPinfo: Integrating GWAS and candidate gene information into functional SNP selection for genetic association studies. Nucleic Acids Res. 2009, 37, W600-W605. [CrossRef]

61. Andreassen, O.A.; Thompson, W.K.; Schork, A.J.; Ripke, S.; Mattingsdal, M.; Kelsoe, J.R.; Kendler, K.S.; O'Donovan, M.C.; Rujescu, D.; Werge, T.; et al. Improved detection of common variants associated with schizophrenia and bipolar disorder using pleiotropy-informed conditional false discovery rate. PLoS Genet. 2013, 9. [CrossRef] [PubMed]

62. Chang, C.C.; Chow, C.C.; Tellier, L.C.; Vattikuti, S.; Purcell, S.M.; Lee, J.J. Second-generation PLINK: Rising to the challenge of larger and richer datasets. Gigascience 2015, 4. [CrossRef] [PubMed]

63. Purcell, S.; Neale, B.; Todd-Brown, K.; Thomas, L.; Ferreira, M.; Bender, D.; Maller, J.; Sklar, P.; de Bakker, P.; Daly, M.; et al. PLINK: A toolset for whole-genome association and population-based linkage analysis. Am. J. Hum. Genet. 2007, 81, 559-575. [CrossRef] [PubMed]

64. GAS Power Calculator. Available online: http://csg.sph.umich.edu/abecasis/cats/gas_power_calculator/ (accessed on 10 September 2019).

65. SNP-NCBI. Available online: https://www.ncbi.nlm.nih.gov/snp/ (accessed on 10 September 2019).

66. Barrett, J.C.; Fry, B.; Maller, J.; Daly, M.J. Haploview: Analysis and visualization of LD and haplotype maps. Bioinformatics 2005, 21, 263-265. [CrossRef] [PubMed]

67. RStudio Team RStudio: Integrated Development for R. RStudio. Available online: http://www.rstudio.com/ (accessed on 5 July 2019).

68. R Core Team. R: A Language and Environment for Statistical Computing; R Foundation for Statistical Computing: Vienna, Austria, 2019; Available online: http://www.R-project.org/ (accessed on 5 July 2019).

69. Zhang, K.; Calabrese, P.; Nordborg, M.; Sun, F. Haplotype block structure and its applications to association studies: Power and study designs. Am. J. Hum. Genet. 2002, 71, 1386-1394. [CrossRef] 
70. Bonafede, M.; Sapra, S.; Shah, N.; Tepper, S.; Cappell, K.; Desai, P. Direct and indirect healthcare resource utilization and costs among migraine patients in the United States. Headache J. Head Face Pain 2018, 58, 700-714. [CrossRef]

71. Ruszczycki, B.; Szepesi, Z.; Wilczynski, G.M.; Bijata, M.; Kalita, K.; Kaczmarek, L.; Wlodarczyk, J. Sampling issues in quantitative analysis of dendritic spines morphology. BMC Bioinform. 2012, 13, 213. [CrossRef]

72. Harriott, A.M.; Schwedt, T.J. Migraine is associated with altered processing of sensory stimuli. Curr. Pain Headache Rep. 2014, 18, 458. [CrossRef]

(C) 2019 by the authors. Licensee MDPI, Basel, Switzerland. This article is an open access article distributed under the terms and conditions of the Creative Commons Attribution (CC BY) license (http://creativecommons.org/licenses/by/4.0/). 